\title{
Transmission Electron Microscopy of the Gastrointestinal Tract of Nile Perch Lates niloticus
}

\author{
Uso de Microscopía Electrónica de Transmisión para Visualizar el \\ Tracto Gastrointestinal de la Perca del Nilo Lates niloticus
}

\author{
V. T. Namulawa*; C. D. Kato**; E. Nyatia**; J. Rutaisire ${ }^{* * * *} \&$ P. J. Britz ${ }^{* * * * *}$
}

NAMULAWA, V. T.; KATO, C. D.; NYATIA E.; RUTAISIRE, J. \& BRITZ, P. J. Transmission electron microscopy of the gastrointestinal tract of Nile perch Lates niloticus. Int. J. Morphol., 33(2):751-758, 2015.

SUMMARY: The ultrastructure of the gastrointestinal tract of Nile perch was described using Transmission Electron Microscopy standard procedures. Investigations revealed the presence of mucous cells, blood vessels and oil droplets plus several nerve cells and muscle bundles in the oral cavity. Further observations revealed columnar epithelial cells in the oesophagus, with a ragged surface, high electron dense cytoplasm, intercellular spaces, mitochondria and mucus granules. The lamina propria of the oesophagus was composed of loose connective tissue, blood vessels, nerve cells and several leucocytes, while the muscularis externa was composed of striated muscle bundles with the a $\mathrm{Z}$ line, A band and I band. The stomach was characterized by mucosal glandular cells with electron dense granules, a prominent nucleus, mitochondria, and secretory canaliculi. The liver had an isotropic parenchyma composed of several hepatocytes with a single spherical euchromatic nucleus. The exocrine pancreatic cells in the liver occurred around large blood vessels, had large centrally positioned nuclei with electron dense nucleolus, electron dense granules, Rough Endoplasmic Reticulum, and mitochondria which dominated the cytoplasm of pancreatic cells.

KEY WORDS: Ultrastructure; Gastrointestinal tract; Nile perch.

\section{INTRODUCTION}

Nile perch Lates niloticus (Linnuaeus 1758), is a freshwater carnivorous fish, of the order Perciformes, family Centropomidae, subfamily Latidae and genus Lates. The fish occurs in the Nile basin, in the Congo basin and in West Africa (Ebinger, 1989; Otero, 2004; Otero et al., 2010). In Uganda Nile perch is a high value fish (Benkenstein, 2011), however limited efforts have been put towards its conservation, given its high fecundity (Hopson, 1972), but the excessive harvest of this fish has caused a threat to its population (Katurole \& Wadanya, 2012) stimulating several strategies towards sustainable utilization of this fishery, including controlled rearing of this fish. It is therefore important to have a prior understanding of the structure of its digestive system, to guide its future potential culture undertakings. Previous studies on Nile perch have focused on its genetics (Mwanja et al., 2012), ecology (OgutuOhwayo, 2004; Nkalubo et al., 2014), population (Downing et al., 2013) and reproduction (Kahwa, 2013), however, limited studies (Namulawa et al., 2013) have engaged the structure of its digestive system.

The morphology of the digestive system in fish has been widely studied because this explains the digestive processes including ingestion, food breakdown and absorption (dos Santos et al., 2011; Canan et al., 2012; Naguib et al., 2011) Similarly, several investigations (Mir et al., 2012; Hassan, 2013; Vajhi et al., 2013), have been done on the ultrastructure of the digestive system of fish, because these give a detailed anatomical understanding of the system. However, no information is available on the ultrastructure of the digestive system of Nile perch, yet such information is important to guide physiological and structural alterations caused by either infections or the environment. It is therefore important to study the transmission electron

\footnotetext{
* Aquaculture Research and Development Center, Kampala, Uganda.

** College of Veterinary Medicine, Animal Resources and BioSecurity, Makerere University, Kampala, Uganda.

*** National Agricultural Research Organization, Entebbe, Uganda.

***** Department of Ichthyology \& Fisheries Science, Rhodes University, Grahamstown, South Africa.
} 
microscopy of the digestive system of Nile perch to guide future research on the culture of Nile perch.

\section{MATERIAL AND METHOD}

Sample collection. Five samples of Nile perch of $1,1.5$, $2.6,4$ and $5 \mathrm{~kg}$ were collected from Lake Victoria in Uganda, in waters around Kiggungu fish landing site, located $32^{\circ} 26^{\prime}$ $15^{\prime}$ "E, $00^{\circ} 2$ ' 49" N. The samples were caught using long lines (hook No. 4-9).

Transmission Electron Microscopy (TEM). Fragments of gut sections ( $1 \mathrm{~mm} \times 1 \mathrm{~mm}$ ) previously fixed in $2.5 \%$ glutaldehyde were rinsed in $0.1 \mathrm{M}$ phosphate buffer. The specimens were then post fixed in $1 \%$ buffer osmium tetraoxide (OS4) at $\mathrm{pH} 7.2$ for 90 minutes at room temperature; the samples were then washed with $0.1 \mathrm{M}$ phosphate buffer for $20 \mathrm{~min}$ followed by serial dehydration in ethanol $(30 \%, 50 \%, 70 \%, 80 \%, 90 \%$ and absolute) for $11 / 2$ hours. This was followed by a wash in propylene oxide for 30 minutes, then in a series of resin and propylene oxide (75/25 pro-resin, 50/50 pro-resin, $25-75$ pro-resin) for 3 hours, and in pure resin overnight. The samples were then embedded in pure resin for 36 hours at $60^{\circ} \mathrm{C}$. Samples sections of $1.2 \mathrm{~nm}$ were then stained with uranyl acetate and lead citrate before examination with a JEOL JEM 1210 TEM.

\section{RESULTS}

Oral cavity. TEM in the oral cavity revealed the presence of mucous cells, blood vessels and oil droplets in the submucosa. Several nerve cells were sandwiched by muscle bundles in the tongue (Fig. 1).

Oesophagus. TEM investigations of the oesophagus revealed that the epithelium was composed of columnar cells (Fig. 2), with a ragged surface towards the lumen.

Three cell types constituted the oesophagus epithelium - mucous, glandular and endocrine (Fig. 3). Type A cells (T1) presented with a ragged surface, a high electron dense cytoplasm and a small elongate irregular nucleus, an electron light cytoplasm, and a round prominent centrally located nucleus in other sections, plus several intercellular spaces, mitochondria and mucus granules at the cell apical ends. Type B cells (T2) appeared light, with an electron-light cytoplasm; the cells had several centrally located organelles in addition to two granulated nuclei.

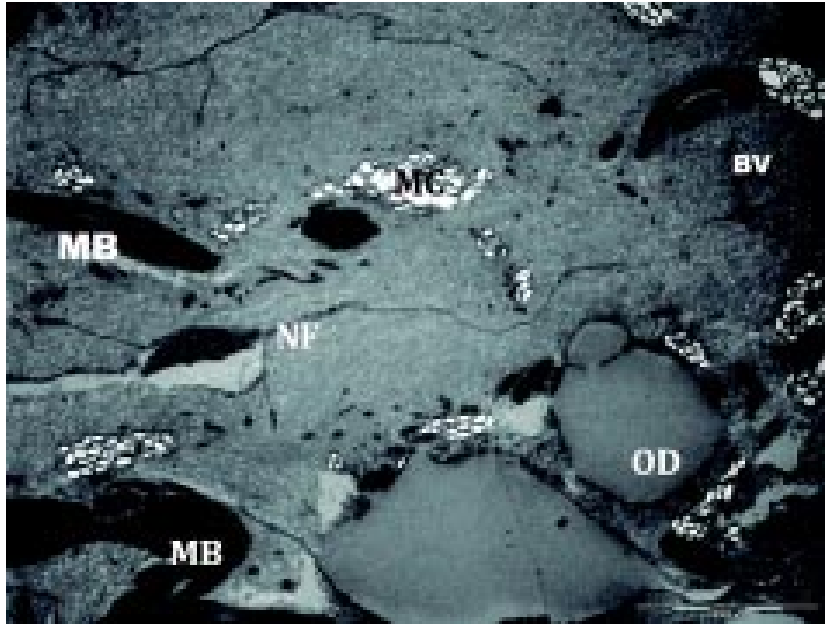

Fig. 1. TEM micrograph of the tongue sections. $M C=$ Mucus cells, $\mathrm{MB}=$ Muscle bundles, $\mathrm{OD}=$ Oil droplets, $\mathrm{NF}=$ Nerve fibers, $\mathrm{BV}=$ Blood vessel.

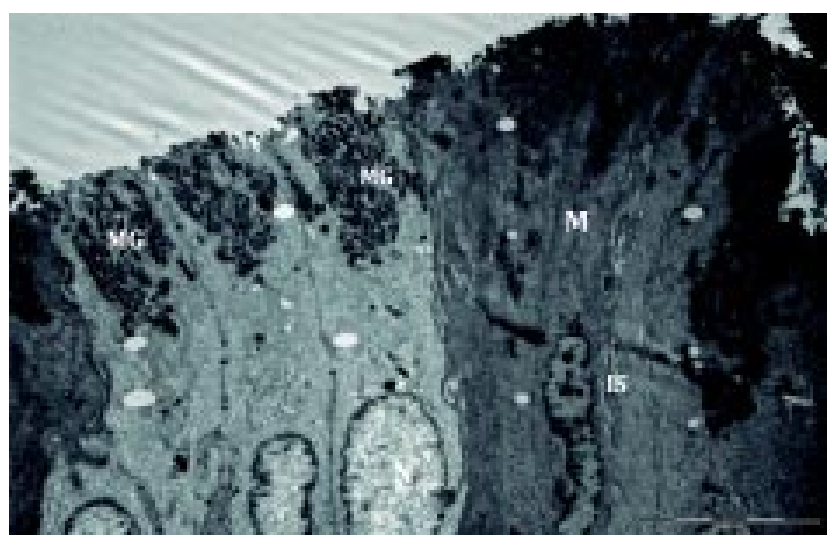

Fig. 2. Columnar cells of the oesophagus. $\mathrm{N}=$ Nucleus, $\mathrm{MG}=$ Mucous granules, $\mathrm{IS}=$ Intercellular space, $\mathrm{M}=$ Mitochondria.

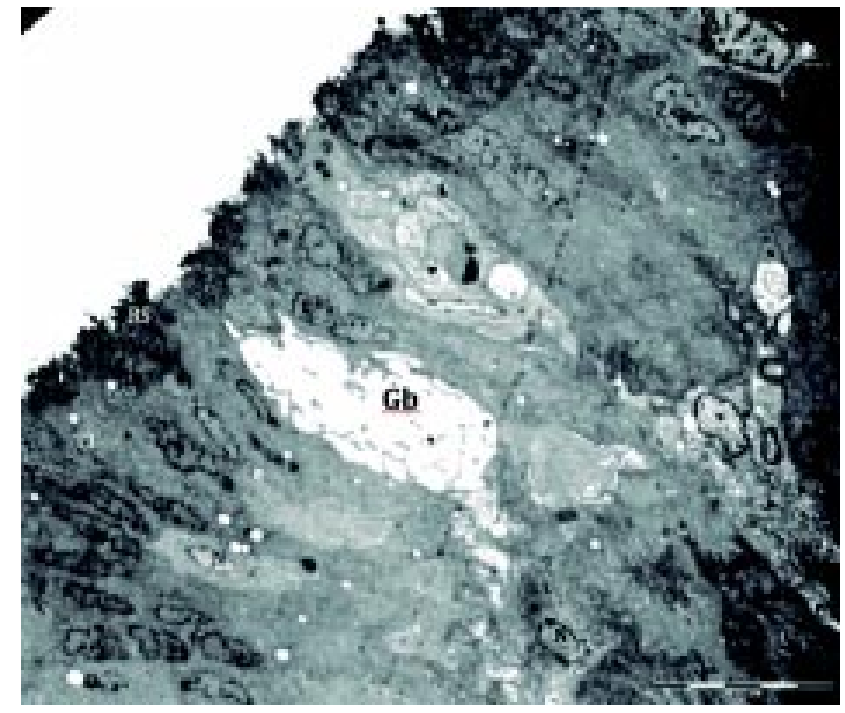

Fig. 3. Cells of the oesophagus epithelium. T1= Type A cell, T2= Type $\mathrm{B}$ cell, $\mathrm{Gb}=$ Goblet cell, $\mathrm{RS}=$ Ragged surface, $\mathrm{N}=$ Nucleus. 
The third cell type in the epithelium was the goblet cell (Gb) which had an electro-lucent cytoplasm and had no visible nucleus.

The lamina propria (Fig. 4) was composed of loose connective tissue, blood vessels, and nerve cells with prominent neural transmitter substance, and fibroblasts that appeared with networked tubules. Several leucocytes, such as neutrophils, basophils, and eosinophils plus lymphocytes of varying sizes were also a common occurrence.
The tunica muscularis (Fig. 5) was composed of striated muscle fibers with a $\mathrm{Z}$ line, A band and I band, nerve cells commonly occurred between the muscle bundles.

Stomach. TEM investigations performed on stomach sections revealed several cells in the mucosa, sub mucosa and tunica muscularis. The epithelium was composed of apical cells with an electron dense cytoplasm. The surface of apical cells had microvilli towards the lumen and

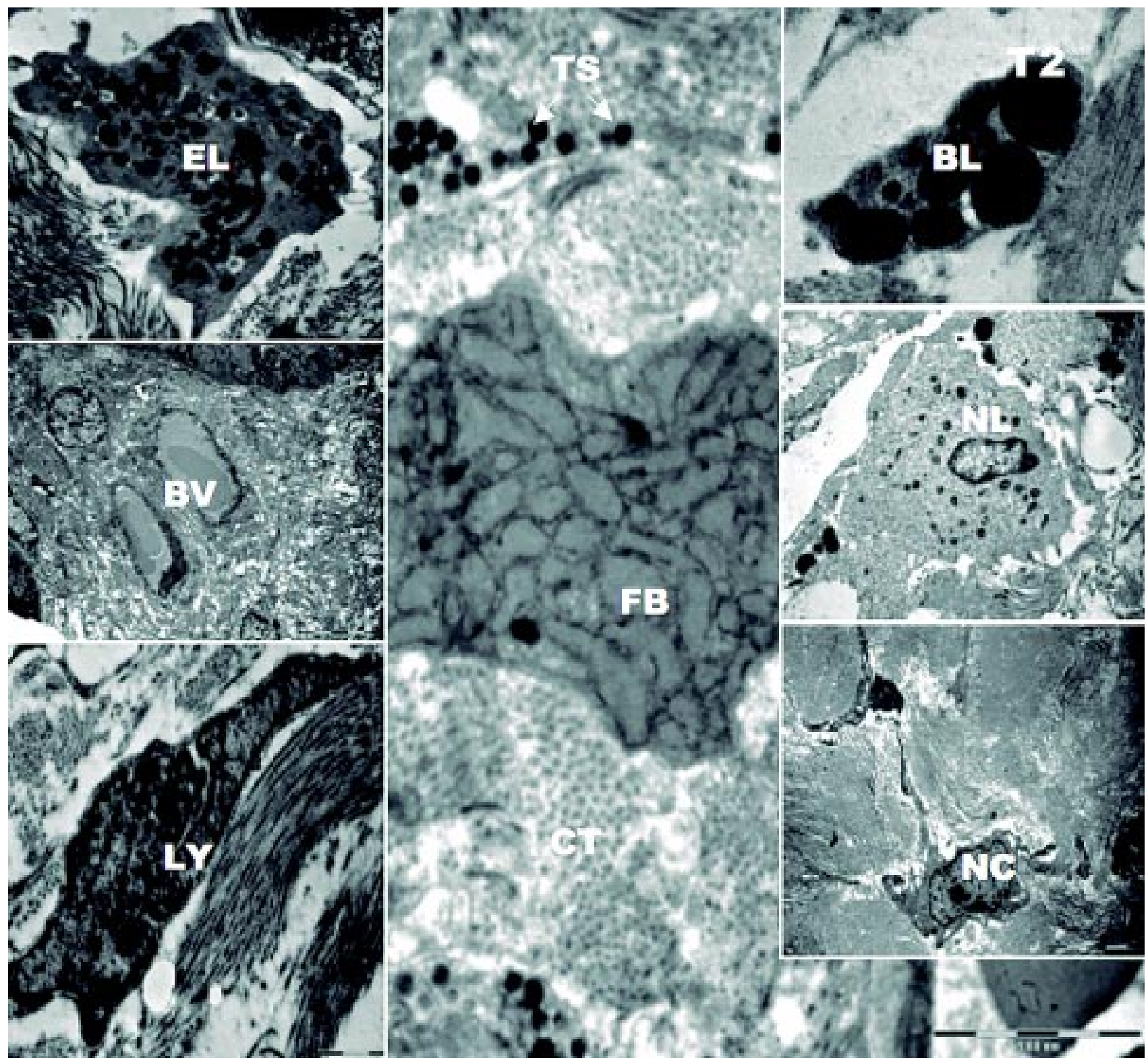

Fig. 4. Section of the submucosa of the oesophagus. $\mathrm{BV}=$ Sub mucosal blood vessels, $\mathrm{CT}=$ connective tissue (both $\mathrm{X} 5000 \mathrm{~nm}$ ), NC= Nerve cell in the submucosal plexus (notice the electron dense neurotransmitter substances) (X5000 nm), EL= Eosinophil Leukocyte with specific electron dense granules in the cytoplasm $(X 2000 \mathrm{~nm}), \mathrm{NL}=$ Neutrophilic Leukocyte with fine specific granules and a centrally located nucleus (X2000 nm), BL= Basophilic Leukocyte with no nucleus observed, electron dense granules in the cytoplasm (X2000 nm), FB= Fibroblast (X10000), LY= Lymphocyte (X10000). 


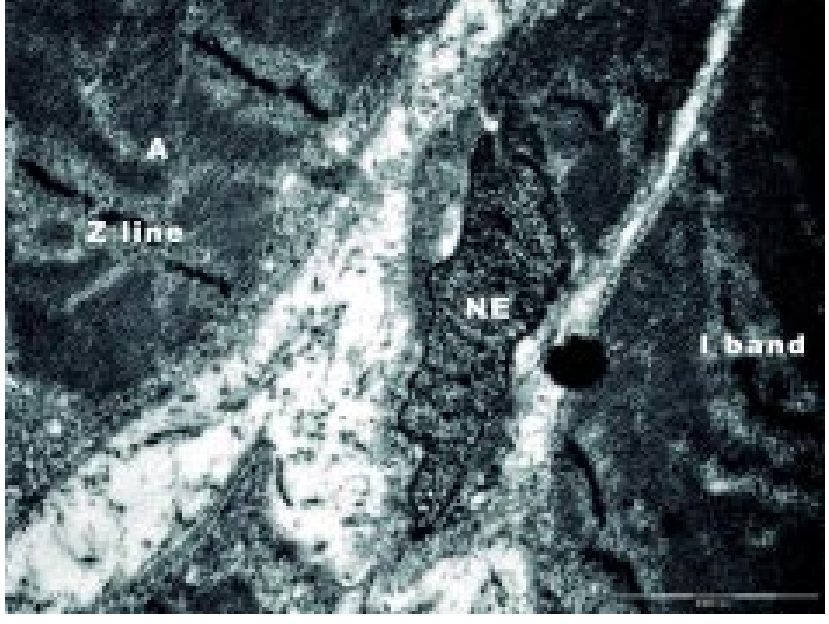

Fig. 5. Striated muscle of the oesophagus. NE= Nerve ending.

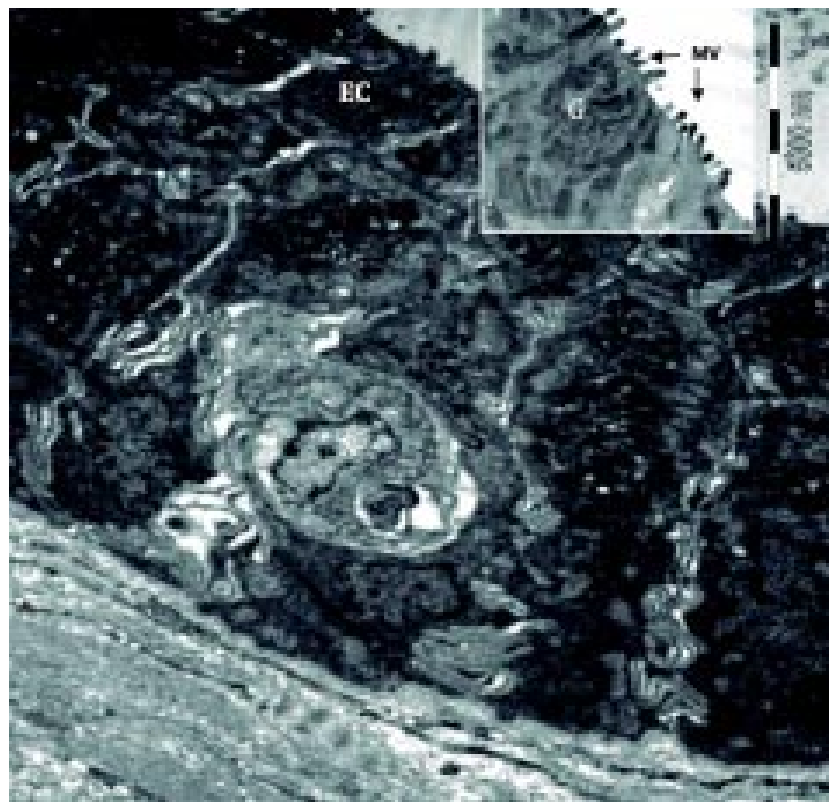

Fig. 6. Section of the stomach epithelial region. $\mathrm{EC}=$ Epithelial cell, $\mathrm{G}=$ Granules, $\mathrm{JC}=$ Junction complex, MV= Microvilli.

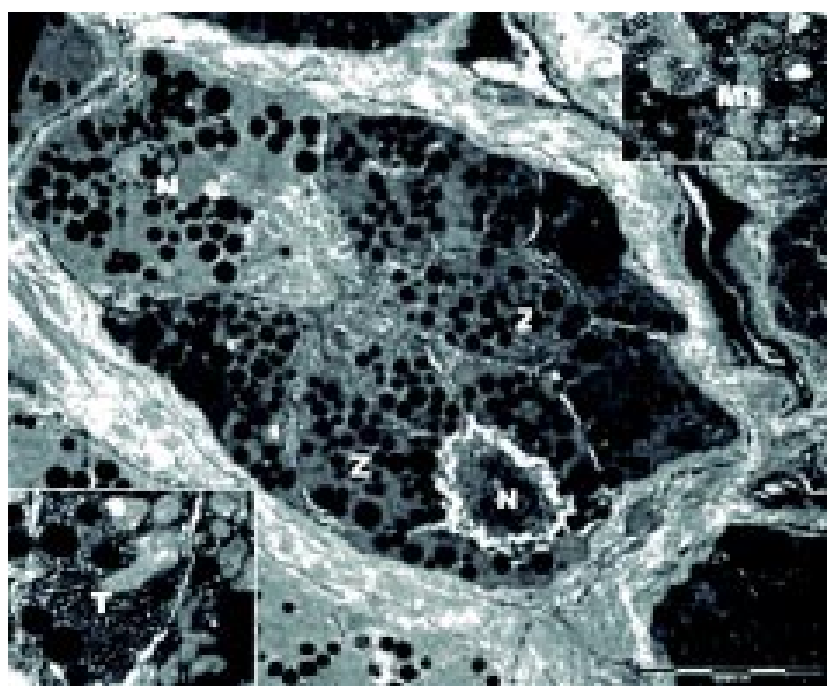

Fig. 7. Gastric glands acinar. $\mathrm{Z}=\mathrm{Zymogen}$ granules, $\mathrm{T}=$ Tubulovesicular system, $\mathrm{Mt}=$ Mitochondria, $\mathrm{N}=$ Nucleus.

junction complexes running alongside the apical cells (Fig. 6). The mucosal glandular cells were characterized by electron dense granules, a prominent nucleus, mitochondria, and secretory canaliculi forming the tubular vesicle system. The glandular cells in the stomach were arranged in several acinar (Fig. 7). The mucosa was composed of several lymphocytes and lymphoid nodule (Peyer's patches), while the tunica muscularis consisted of several smooth muscle bundles (Fig. 8).

Liver. TEM investigations of the liver revealed that this organ had an isotropic parenchyma. The parenchyma was composed of several cells, including the polygonal and oblong hepatocytes with a single spherical euchromatic nucleus. The hepatocyte cytoplasm was large and contained glycogen, lysosome, oil droplets and mitochondria (Fig. 9). Exocrine pancreatic cells (Fig. 10)

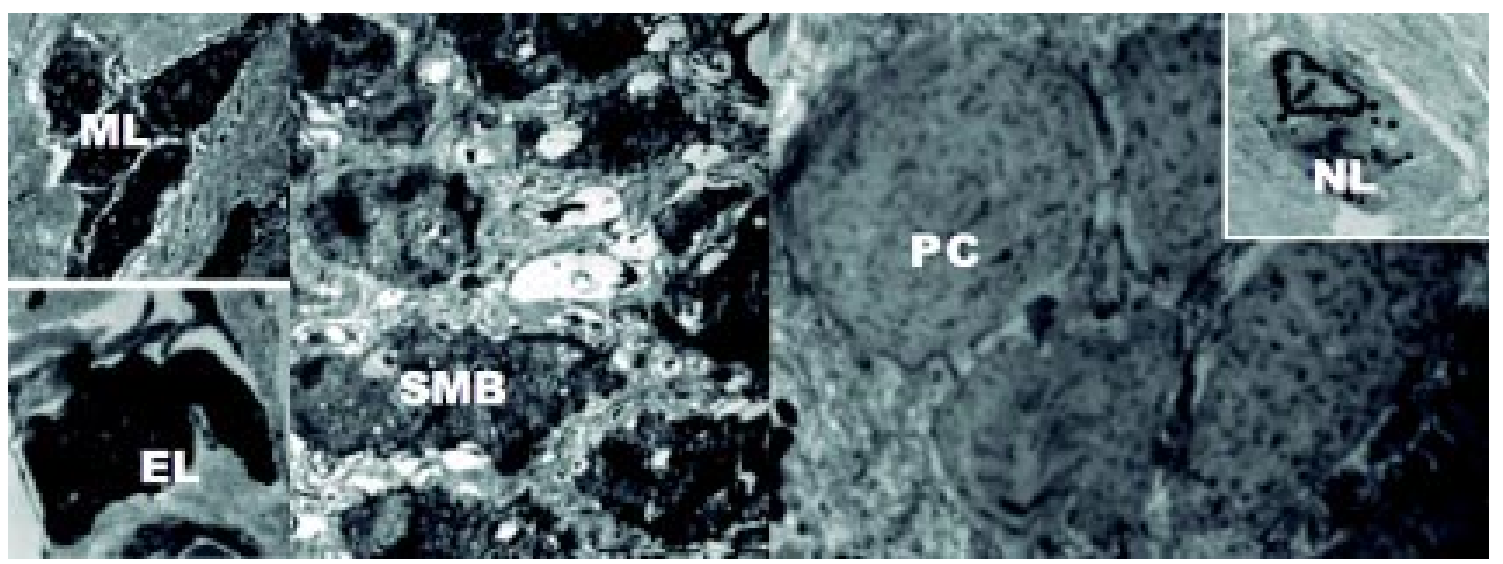

Fig. 8. Section of the stomach submucosa. $\mathrm{SMB}=$ Smooth Muscle bundles, $\mathrm{EL}=$ Eosinophilic Leucocyte $(X 5000 \mathrm{~nm})$, $\mathrm{NL}=$ Neutrophilic leucocyte $(X 5000), \mathrm{ML}=$ Migratory lymphocyte $(\mathrm{X} 10000 \mathrm{~nm}), \mathrm{PC}=$ Peyer's patches $(\mathrm{X} 2000)$. 
occurred around large blood vessels; and had a large centrally positioned nucleus of $3 \mathrm{~mm}$ to $4 \mathrm{~mm}$ in diameter, with an electron dense nucleolus that assumed a prominent round shape and had of $0.7 \mathrm{~mm}$ to $2 \mathrm{~mm}$ in diameter. Electron dense granules of $0.6 \mathrm{~mm}$ to $1 \mathrm{~mm}$ diameter, Rough Endoplasmic Reticulum (RER), and mitochondria dominated the cytoplasm of pancreatic cells. Sinusoids containing blood cells, endothelial cells and Stellate macrophage (Kupffer cells) commonly occur between hepatocytes. Several mucous cells and nucleated oblong red blood cells were commonly observed close to the hepatocytes.

Intestines. Micrographs of caeca and intestine sections (Fig. 11) showed the presence of several cells in the mu-

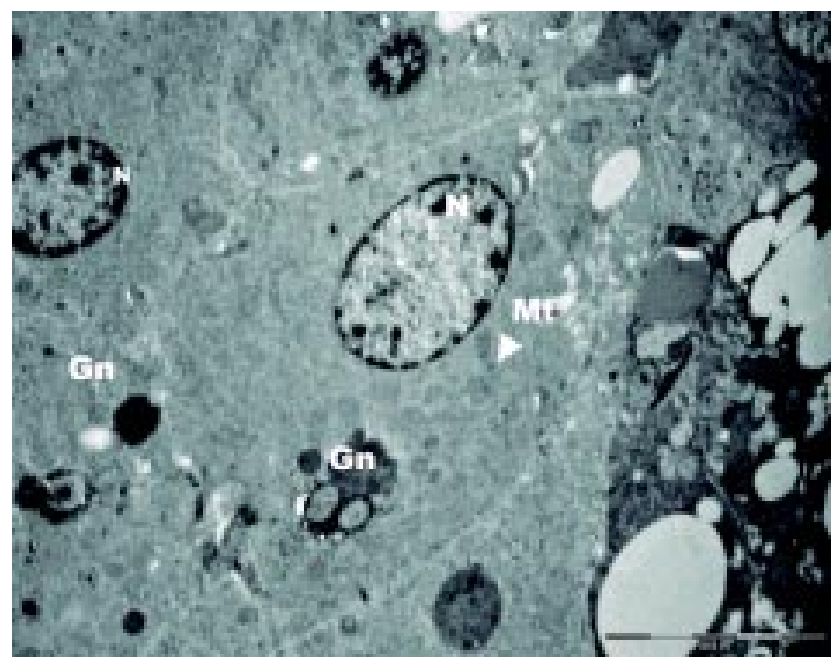

Fig. 9. Liver hepatocyte. $\mathrm{N}=$ Nucleus, $\mathrm{Gn}=$ Glycogen granule, $\mathrm{Mt}=$ Mitochondria.

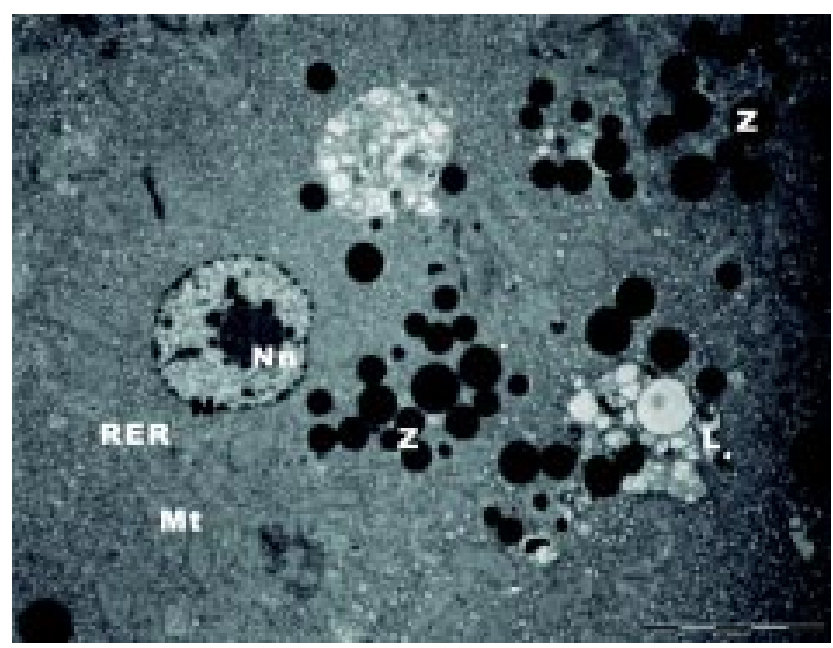

Fig. 10. Section of the hepatopancreas. $\mathrm{Nn}=$ Nucleolus, $\mathrm{Mt}=$ Mitochondria, RER= Rough Endoplasmic Reticulum, Z= Zymogens granules, $\mathrm{N}=$ Nucleus, $\mathrm{L}=$ Lumen of the pancreatic acinar. cosa, sub mucosa and muscularis externa. The epithelium was composed of rodlet cells, enterocytes, goblet cells and migratory lymphocytes. The rodlet cells had an eccentric euchromatic nucleus with electron dense granules; a thick septum enclosed each rodlet cell, separating it from its immediate neighbor. The enterocytes were columnar, with an electron dense cytoplasm, a basal located granular nucleus, and microvillus towards the lumen (Fig. 12).

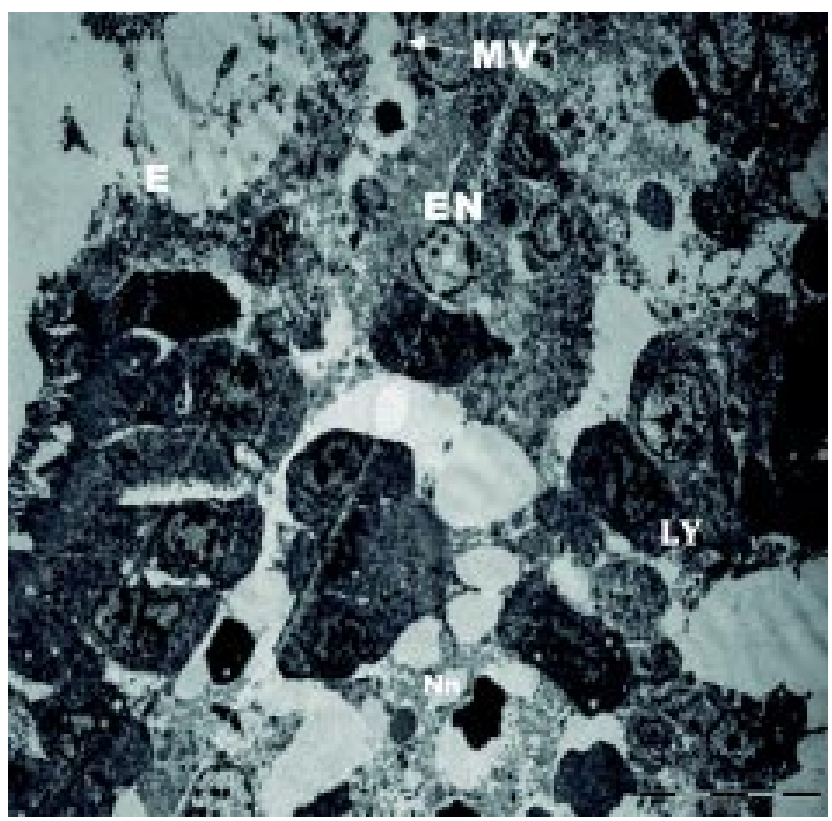

Fig. 11. Intestine mucosal region. $\mathrm{MV}=$ Microvillus, $\mathrm{EN}=$ Enterocyte, LY= Migratory Lymphocytes.

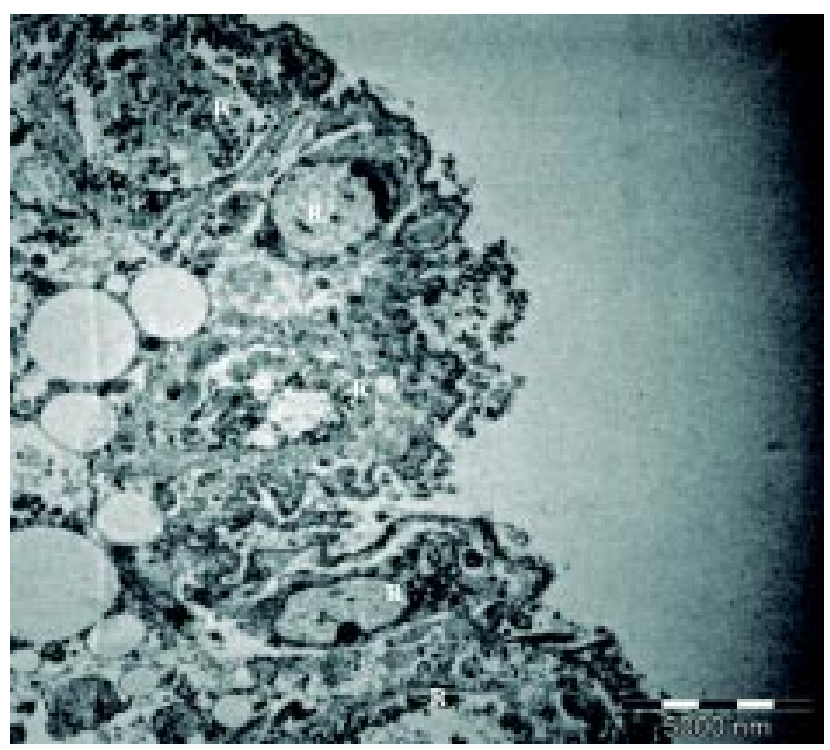

Fig. 12. Caeca region. $\mathrm{R}=$ Rodlet cells, $\mathrm{RC}=$ lining the epithelium. 


\section{DISCUSSION}

The structures of the digestive system in fish are characteristic to the feeding mode and food type (Monsefi $e t$ al., 2010). TEM investigations in this study revealed the presence of several muscle bundles and mucus cells in the oral cavity of Nile perch; similar structures have been reported in other carnivores such as the hagfish (Clark \& Summers, 2007; Yashpal et al., 2006). In these studies, skeletal muscles in the oral cavity are reported to facilitate expandability of the cavity to ease swallowing, while the mucous is responsible for lubricating the oral path to ease prey movement towards the oesophagus. This suggests that these structures play the same roles in Nile perch, since Nile perch is similarly a carnivorous fish that feeds on live prey. Additionally, several neurons occur in the oral cavity of Nile perch (Fig. 1). This observation suggests that the gustatory sense plays a vital role during ingestion in Nile perch as observed in the Sea bream Sparua aurata (El Bakary, 2012) and in Clarias gariepinus (Gamal et al., 2012).

Investigations in this study further reveal the presence of a simple columnar epithelium in the Nile perch oesophagus (Figs. 2 and 3). The columnar cells (Fig. 2) are rich with mucous substances (MG) concentrated at the apical ends, suggesting their secretory nature (Ikpegbu et al., 2013). The cells also have villi-like projections, mitochondria and intercellular spaces; similar structures were reported in Solea senegalensis (Arellano et al., 2001) and in Clarias gariepius (El Hafez et al., 2013). These have been suggested to possibly be important for active ion transport; with solutes moving via the intercellular spaces in the epithelia cells. Relatedly, the lamina propria and submucosa regions are composed of loose connective tissue, blood vessels, and nerve cells, fibroblasts and leucocytes, as those observed in other vertebrates (Machado-Santos et al., 2011), with the leucocytes forming part of the gut lymphoid system (Rombout et al., 2011; Sunyer, 2013) Additionally, striated muscle fibers with a $Z$ line, $A$ band and I band, and nerve cells occur in the muscularis externa of the oesophagus (Fig. 5). Similar muscle arrangements have been reported in the Rainbow trout Oncorhynchus mykiss (Geyikog lu et al., 2004) and these together with the nerves possibly work together to effect peristalsis in this region.

TEM investigations in this study further reveal the presence of several zymogens that occur in acinar (Fig. 7) in the mucosa of the stomach of Nile perch. These are glandular cells similarly observed to secrete both hydrochloric acid and pepsinogen in fish (Rebolledo \& Vial, 1979; Ota et al., 1998), in reptiles (Ahmed et al., 2009) and in birds (Selvan et al., 2008). The presence of large numbers of such glandular cells in the stomach of Nile perch could explain how Nile perch is able to effectively break down whole fish, including the bones and the scales using chemical digestion.

Investigations in the liver show the liver hepatocytes (Fig. 9) and of acinar of exocrine and endocrine pancreas localized around hepatic veins (Fig. 10). Similar cells have been reported in Pangasius sanitwongsei (Sayrafi et al., 2011) and Oligosarcus jenynsii (Petcoff et al., 2006), where the liver occurs together with the pancreas to form a hepatopancreas.

TEM investigations show that the epithelium in the caeca and intestine are composed of several cell types; the columnar enterocytes which have microvilli that form a brush border (Fig. 11), the oval shaped rodlet cells and the migratory lymphocytes (Fig. 12). The presence of microvilli on the enterocytes suggests their adaptation to improving the absorption process per unit area. The fact that the pyloric caeca have basically the same histological structure as the rest of the intestine suggests that one of their roles is to increase the gut's absorptive surface area (Houssian \& Dutta, 1998; Albrecht et al., 2001). Additionally, several neutrophils, eosinophils, basophlis, lymphocytes and monocytes were observed in the Nile perch gut by TEM. These cells have been observed in several other animals and are said to be important for the body's immune system (Bloom \& Fawcett, 1993). Several types of enteroendocrine cells are also observed in the mucosa of the caeca and intestine, similar to those observed in the stomach and intestine of Perca fluviatilis, Ameilerus nebulosus (Noaillac-Depeyre \& Gas, 1982) and Ancistrus multispinnis (Satora \& Winnicki, 2000).

Such cells were described as receptor-sensory cells, receiving specific chemical information that stimulates or inhibits secretion (Elbal et al., 1988). Structures similar to lymphoid nodules (Peyer's patches) were also observed in the stomach muscularis. There were similar to those observed in the rats, and have been associated with the lymphatic system (Bloom \& Fawcett). The existence of a strong immune system in the gut region of Nile perch suggests its ability to avoid possible infections that could originate from the ingested food items, given the fact that it ingests live prey that could be infected.

\section{CONCLUSION}

The ultrastructure of the digestive system in Nile perch is characterized by glandular cells, nerve cells, a hepatopancreas, and a lymphoid system. These structures are responsible for the efficient functioning of this system. These findings provide insights into the structure and functioning of the digestive system in this fish. 
ACKNOWLEDGEMENTS. Authors wish to acknowledge the support offered by the World Bank and the Uganda National Council for Science and Technology.

NAMULAWA, V. T.; KATO, C. D.; NYATIA, E.; RUTAISIRE, J. \& BRITZ, P. J. Uso de microscopía electrónica de transmisión para visualizar el tracto gastrointestinal de la perca del Nilo Lates niloticus. Int. J. Morphol., 33(2):751-758, 2015.

RESUMEN: La ultraestructura del tracto gastrointestinal de la perca del Nilo fue descrita utilizando un procedimiento estándar de Microscopía Electrónica de Transmisión (MET). Las investigaciones revelaron la presencia de células mucosas, vasos sanguíneos y pequeñas gotas de aceite, además de varias células nerviosas y haces musculares en la cavidad oral. Nuevas observaciones revelaron células epiteliales columnares en el esófago, con una superficie irregular, citoplasma elevado y electrodenso, espacios intercelulares, mitocondrias y gránulos mucosos. La lámina propia del esófago se compone de tejido conectivo laxo, vasos sanguíneos, células nerviosas y numerosos leucocitos, mientras que la muscular externa se compone de haces musculares estriados, con presencia de la línea Z, banda A y banda I. El estómago se caracteriza por presentar células glandulares mucosas con gránulos electrodensos, un núcleo prominente, mitocondrias y canalículos secretores. El hígado presentó un parénquima isotrópico compuesto de varios hepatocitos con un solo núcleo eucromático y esférico. Las células pancreáticas exocrinas se encontraron alrededor de grandes vasos sanguíneos, presentando grandes núcleos posicionados centralmente, con nucleólos densos, gránulos electrodensos en el retículo endoplasmático rugoso, y mitocondrias, que dominaron el citoplasma de las células pancreáticas.

PALABRAS CLAVE: Ultraestructura; Tracto gastrointestinal; Perca del Nilo.

\section{REFERENCES}

Ahmed, Y. A.; El-Hafez, A. A. E. \& Zayed, A. E. Histological and histochemical studies on the esophagus, stomach and small intestines of Varanus niloticus. J. Vet. Anat., 2(1):35-48, 2009.

Albrecht, M. P.; Ferreira, M. F. N. \& Caramaschi, E. P. Anatomical features and histology of the digestive tract of two related neotropical omnivorous fishes (Characiformes; Anostomidae). $J$. Fish Biol., 58(2):419-30, 2001.

Arellano, J. M.; Storch, V. \& Sarasquete, C. A histological and histochemical study of the oesophagus and oesogaster of the Senegal sole, Solea senegalensis. Eur. J. Histochem., 45(3):27994, 2001.

Benkenstein, A. "Troubled Waters" Sustaining Uganda's Lake Victoria Nile Perch Fishery. Johannesburg, Research Report 9, Governance of Africa's Resources Programme, South African Institute of International Affairs (SAIIA), 2011.
Bloom, W. \& Fawcett, D.W. Bloom and Fawcett. A Text Book of Histology. 12th ed. New York, Chapman \& Hall, 1993.

Canan, B.; de Nascimento, W. S.; da Silva, N. B. \& Chellappa, S. Morphohistology of the digestive tract of the damsel fish Stegastes fuscus (Osteichthyes: Pomacentridae). ScientificWorldJournal, 2012:787316, 2012.

Clark, A. J. \& Summers, A. P. Morphology and kinematics of feeding in hagfish: possible functional advantages of jaws. J. Exp. Biol., 210(Pt. 22):3897-909, 2007.

dos Santos, A. F.; dos Santos, L. N. \& Araújo, F. G. Digestive tract morphology of the Neotropical piscivorous fish Cichla kelberi (Perciformes: Cichlidae) introduced into an oligotrophic Brazilian reservoir. Rev. Biol. Trop., 59(3):1245-55, 2011.

Downing, A. S.; Galic, N.; Goudswaard, K. P.; van Nes, E. H.; Scheffer, M.; Witte, F. \& Mooij, W. M. Was Lates late? A null model for the Nile perch boom in Lake Victoria. PloS One, 8(10):e76847, 2013.

Ebinger, C. J. Tectonic development of the western branch of the East African rift system. Geol. Soc. Am. Bull., 101(7):885-903, 1989.

El Bakary, N. E. S. R. Morphology of the buccal cavity of Sea Bream (Sparus aurata) and its relation to the type of feeding using scanning electronmicroscopy. Glob. Vet., 9(6):779-84, 2012.

El Hafez, E. A. A.; Mokhtar, D. M.; Abou-Elhamd, A. S. \& Hassan, A. H. S. Comparative Histomorphological Studies on Oesophagus of Catfish and Grass Carp. J. Histol., 2013:ID858674, 2013.

Elbal, M. T.; Lozano, M. T. \& Agulleiro, B. The endocrine cells in the gut of Mugil saliens Risso, 1810 (Teleostei): an immunocytochemical and ultrastructural study. Gen. Comp. Endocr., 70(2):231-46, 1988.

Gamal, A. M.; Elsheikh, E. H. \& Nasr, E. S. Morphological adaptation of the buccal cavity in relation to feeding habits of the omnivorous fish Clarias gariepinus: A scanning electron microscopic study. J. Basic Appl. Zool., 65(3):191-8, 2012.

Geyikoglu, F.; Vuraler, Ö. \& Temelli, A. Histological, histochemical and ultrastructural investigations on the esophagus of juvenile Rainbow Trout (Oncorhynchus mykiss). Turk. J. Zool., 28(1):7382, 2004.

Hassan, A. A. Anatomy and Histology of the digestive system of the carnivorous fish, the brown-spotted grouper, Epinephelus chlorostigma (Pisces; Serranidae) from the Red Sea. Life Sci. J., 10(2):2149-64, 2013.

Hopson, A. J. The study of Nile perch (Lates niloticus) (Pisces: Centropomidae) in Lake Chad. London, Overseas Research Publication, Commonwealth Office, Overseas Development Administration Her Majesty's Stationery Office, 19:93, 1972.

Hossian, A. M. \& Dutta, H. M. Assessment of structural and functional similarities and differences between caeca of the bluegill. J. Fish Biol., 53(6):1317-23, 1998. 
Ikpegbu, E.; Ezeasor D. N.; Nlebedum, U. C. \& Nnadozie, O. Morphological and histochemical observations on the oesogaster of the domesticated African catfish (Clarias Gariepinus Burchell, 1822). Bulg. J. Vet. Med., 16(2):88-95, 2013.

Kahwa, D. Gametogenesis, gonadal recrudescence, restraint and Spawning patterns in Nile perch, Lates niloticus (Linnaeus, 1758). $\mathrm{PhD}$ Thesis. Grahamstown, Rhodes University, 2013.

Katurole, G. \& Wadanya, J. A study of impacts of fishing pressure on Nile perch fishery on Lake Victoria (Uganda) using fisher folk community collected data. Kisumu, Lake Victoria Basin Knowledge Management System, United Nations University, 2012.

Machado-Santos, C.; Zeca, S. G.; Abidu-Figueiredo, M.; Ribeiro, I. C. A. \& Sales, A. The esophagus of the crocodilian Caiman latirostris (Reptilia, Crocodylia): histological, histochemical and immunohistochemical study. J. Morphol. Sci., 28(2):113-9, 2011.

Mir, I. H.; Nabi, S. \& Channa, A. Epithelium of the intestinal tract of a freshwater teleost, Schizothorax curvifrons Heckel (Cyprinidae, Cypriniformes, Pisces): An ultrastructural study. Cytologia, 77(4):431-9, 2012.

Monsefi, M.; Gholami, Z. \& Esmaeili, H. R. Histological and morphological studies of digestive tube and liver of the Persian tooth-carp, Aphanius percicus (Actinopterygii Cyprinodontidae). I. U. F. S. J. Biol., 69(1):57-64, 2010.

Mwanja, M. T.; Mwanja, W. W.; Muwanika, V.; Masembe, C. \& Nyakaana, S. Genetic evidence of successful establishment of the Nile perch (Lates spp. L.) in East African lakes and implications for management. Manag. Biol. Invasions, 3(2):77-88, 2012.

Naguib, S. A. A.; EI-Shabaka, H. A. \& Ashour F. Comparative histological and ultrastructural studies on the stomach of Schilbe mystus and the intestinal swelling of Labeo niloticus. J. Am. Sci., 7(8):251-63, 2011.

Namulawa, V. T.; Kato, C. D.; Nyatia, E.; Rutaisire, J. \& Britz, P. Scanning electron microscopy of the gastrointestinal tract of nile perch (Lates niloticus, Linneaus, 1758). Int. J. Morphol., 31(3):1068-75, 2013.

Nkalubo, W.; Chapman, L. \& Muyodi, F. Feeding ecology of the intensively fished Nile perch, Lates niloticus, in Lake Victoria, Uganda. Aquat. Ecosyst. Health Manag., 17(1):62-9, 2014

Noaillac-Depeyre, J. \& Gas, N. Ultrastructure of endocrine cells in the stomach of two teleost fish, Perca fluviatilis L. and Ameiurus nebulosus L. Cell Tissue Res., 221(3):657-78, 1982.

Ogutu-Ohwayo, R. Management of the Nile perch, Lates niloticus fishery in Lake Victoria in light of the changes in its life history characteristics. Afr. J. Ecol., 42(4):306-14, 2004.

Ota, H.; Nakayama, J.; Momose, M.; Kurihara, M.; Ishihara, K.; Hotta, K. \& Katsuyama, T. New monoclonal antibodies against gastric gland mucous cell-type mucins: a comparative immunohistochemical study. Histochem. Cell Biol., 110(2):113-9, 1998.
Otero, O. Anatomy, systematics and phylogeny of both Recent and fossil latid fishes (Teleostei, Perciformes, Latidae). Zool. J. Linnean Soc., 141(1):81-133, 2004.

Otero, O.; Pinton, A.; Mackaye, H. T.; Likius, A.; Vignaud, P. \& Brunet, M. The early/late Pliocene ichthyofauna from Koro-Toro, Eastern Djurab, Chad. Geobios, 43(2):241-51, 2010.

Petcoff, G. M.; Diaz, A. O.; Escalante, A. H. \& Goldemberg, A.L., 2006. Histology of the liver of Oligosarcus jenynsii (Ostariophysi, Characidae) from Los Padres Lake, Argentina. Iheringia Sér. Zool., 96(2):205-8, 2006.

Rebolledo, I. M. \& Vial, J. D. Fine structure of the oxynticopeptic cell in the gastric glands of an elasmobranch species (Halaelurus chilensis). Anat. Rec., 193(4):805-22, 1979.

Rombout, J. H.; Abelli, L.; Picchietti, S.; Scapigliati, G. \& Kiron, V. Teleost intestinal immunology. Fish Shellfish Immunol., 31(5):61626, 2011.

Satora, L. \& Winnicki, A. Stomach as an additional respiratory organ, as exemplified by Ancistrus multispinnis [Couvier et Valenciennes, 1937], Siluriformes, Teleostei. Acta Ichthyol. Piscat., 30(1):73-9, 2000.

Sayrafi, R.; Najafi G.; Rahmati-holasoo H.; Hooshyari A.; Akbari, R.; Shokrpoor, S. \& Ghadam, M. Histological study of hepatopancreas in Hi Fin Pangasius (Pangasius sanitwongsei). Afr. J. Biotechnol., 10(17):3463-6, 2011.

Selvan, P. S.; Ushakumary, S. \& Ramesh, G. Studies on the histochemistry of the proventriculus and gizzard of post-hatch guinea fowl (Numida meleagris). Int. J. Poult. Sci., 7(11):1112-6, 2008.

Sunyer, J. O. Fishing for mammalian paradigms in the teleost immune system. Nat. Immunol., 14(4):320-6, 2013.

Vajhi, A. R.; Zehtabvar, O.; Masoudifard, M.; Moghim, M. \& Akhtarzade, M. Digestive system anatomy of the Acipenser persicus: New features. Iran. J. Fish. Sci., 12(4):939-46, 2013.

Yashpal, M.; Kumari, U.; Mittal, S. \& Mittal, A. K. Surface architecture of the mouth cavity of a carnivorous fish Rita rita (Hamilton, 1822) (Siluriformes, Bagridae). Bel. J. Zool., 136(2):155-62, 2006.

\section{Correspondence to:}

Namulawa Victoria Tibenda

Aquaculture Research \& development Center

P. O. Box 530

Kampla

UGANDA

Email: tibendavyky@yahoo.com

Received: 17-12-2014

Accepted: 12-03-2015 